\title{
Mercury and selenium concentrations and their interrelations in organs from dental staff and the general population
}

\author{
Magnus Nylander, Jan Weiner
}

\begin{abstract}
Mercury (Hg) and selenium (Se) concentrations were determined by radiochemical neutron activation analysis in samples from the pituitary glands, occipital cortices, renal cortices, abdominal muscles, and thyroid glands of cadavers. Samples were retrieved from dental stafi occupationally exposed to $\mathrm{Hg}$ and from the general population. Increased concentrations of both $\mathrm{Hg}$ and $\mathrm{Se}$ in samples from dental staff showed that Se accumulated together with Hg. Regression analysis of data from the pituitary glands and occipital cortices of dental staff indicated the accumulation of Se at a rough stoichiometric ratio of $1: 1$ with Hg. The same stoichiometric ratio between the elements was seen in the renal cortices from the general population. The regression analysis showed that a substantial fraction of Se was not associated with $\mathrm{Hg}$; it is assumed that this corresponds to biologically available Se. Concentrations of biologically available Se decreased with advancing age in the pituitary gland, but not in other organs, and varied appreciably between organs.
\end{abstract}

Mercury $(\mathrm{Hg})$ is a non-essential heavy metal the compounds of which differ in metabolism and toxicity. Due to its volatility elemental mercury $\left(\mathrm{Hg}^{0}\right)$ is the most important form from the point of view of occupational hygiene. After uptake in the lungs $\mathrm{Hg}^{0}$ is oxidised to mercuric mercury $\left(\mathrm{Hg}^{2+}\right)$ in the blood and other tissues. ${ }^{1}$

As a result of preparing and working with amalgam dental staff are exposed to mercury vapour and particulates. ${ }^{2}$ This exposure implies a potential risk

Department of Environmental Hygiene, Karolinska Institute, PO Box 604 00, S-104 01 Stockholm, Sweden

M Nylander

National Board of Occupational Safety and Health, S-171 84 Solna, Sweden

$\mathrm{J}$ Weiner for deleterious effects. ${ }^{4-6}$ Recently interest has focused on the possibility of health effects in the general population due to exposure to inorganic mercury from amalgam restorations. ${ }^{7-9}$ Amalgam fillings continuously emit $\mathrm{Hg}^{0}$ vapour, which is absorbed in the lungs and distributed to various organs. ${ }^{810-12}$ Mercury released from amalgam is a predominant source of exposure to inorganic mercury in the general population. ${ }^{13}$ The other major source is organic $\mathrm{Hg}$ (methylmercury $(\mathrm{MeHg})$ ) in food. In mammals $\mathrm{MeHg}$ is converted into inorganic $\mathrm{Hg}$, assumed to be $\mathrm{Hg}^{2+}$. In several tissues from humans with high oral intake of $\mathrm{MeHg}$ a significant fraction of $\mathrm{Hg}$ is in the form of $\mathrm{Hg}^{2+}$. Usually the kidney contains the highest fraction in this form. ${ }^{1}$

Selenium (Se) is an essential trace element in several species including humans. In experimental studies on rodents, combined administration of inorganic $\mathrm{Hg}$ and $\mathrm{Se}$ (mostly selenite $\left(\mathrm{SeO}_{3}{ }^{2-}\right)$ ) altered their protein binding and sub-cellular and organ distribution, and a significant part became attached to certain high molecular weight protein fractions in a 1:1 stoichiometric ratio. ${ }^{14-17}$ Combined administration also resulted in an increased long term retention of the elements. ${ }^{18-21}$

When $\mathrm{Se}$ and $\mathrm{Hg}$ were administered to mice at highly variable ratios after an initial elimination phase their stoichiometric ratio in the whole body approached 1:1. ${ }^{22}$ Studies on organs from seals, dolphins, and porpoises have also shown a roughly 1:1 relation between $\mathrm{Hg}$ and $\mathrm{Se}$ in liver and brain tissues over a wide range of concentrations. ${ }^{23}{ }^{24}$ In 1975 Kosta et al reported a roughly 1:1 stoichiometric ratio of $\mathrm{Hg}$ and $\mathrm{Se}$ at high concentrations in several organs of former $\mathrm{Hg}$ miners. ${ }^{25} \mathrm{We}$ also found a high correlation between high total $\mathrm{Hg}$ and Se concentrations in four pituitary glands from dental staff. ${ }^{26}$ The main purpose of our present work was to further elucidate the relation between $\mathrm{Hg}$ and Se concentrations in several tissues from subjects with varying exposure to mercury vapour.

Materials and methods

Pituitary glands, occipital cortices, renal cortices, abdominal muscle and a few samples of thyroid 
Table 1 Mercury and Se concentrations ( $\mu$ mol/kg wet weight) in tissue samples from dental personnel *

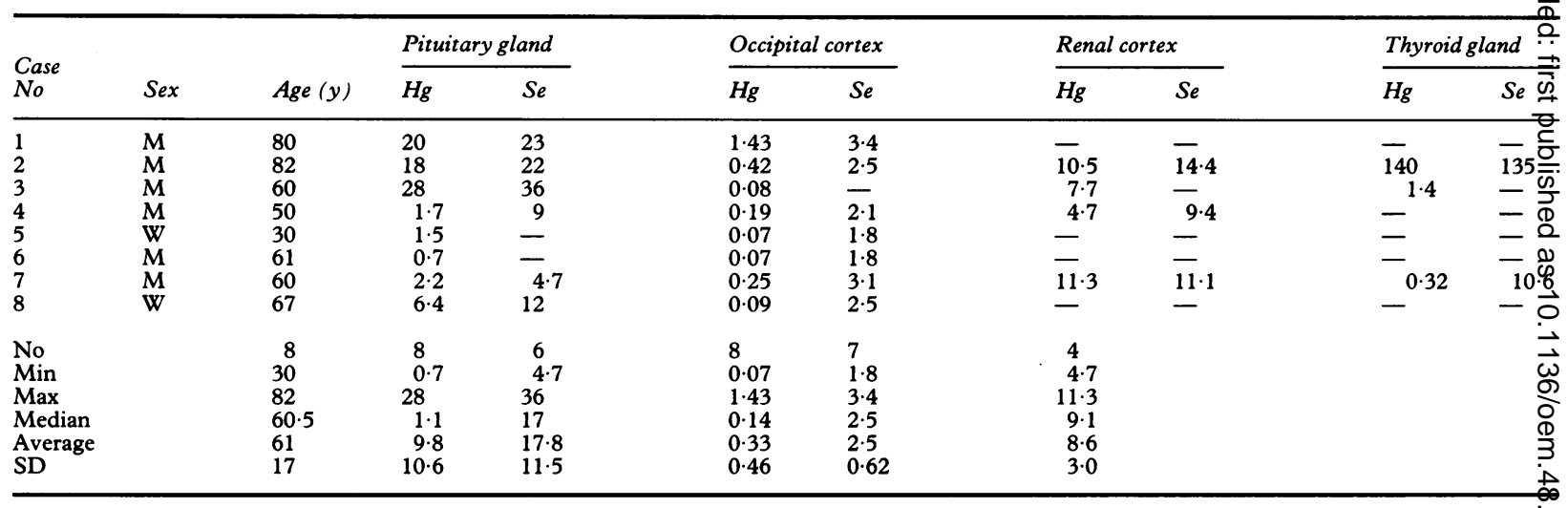

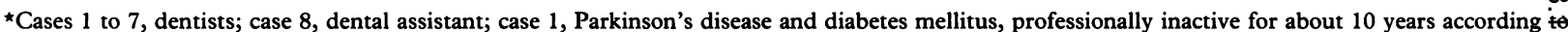

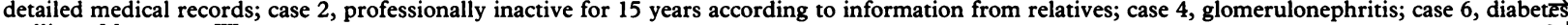
mellitus. $\mathrm{M}=\operatorname{man}, \mathrm{W}=$ woman.

glands were collected at necropsy from seven dentists and one dental assistant (table 1). The samples were collected at different pathology departments and at the National Institute of Forensic Medicine in Stockholm. Pituitary glands, occipital cortices, renal cortices, and abdominal muscle samples, from subjects without known occupational exposure to $\mathrm{Hg}$ were also collected (table 2). All deaths had been sudden and unexpected. The sampling was carried out at the National Institute of Forensic Medicine.

According to detailed medical records and information from relatives, two of the dentists had not been professionally active for several years due to retirement and incapacitating chronic illness (cases 1 and 2, table 1). Medical records and necropsy reports indicated that the others had been professionally

Table 2 Mercury and Se concentrations ( $\mu$ mol/kg wet weight) in tissue samples from subjects in the general population ${ }^{\star}$

\begin{tabular}{|c|c|c|c|c|c|c|c|c|c|c|}
\hline \multirow{2}{*}{$\begin{array}{l}\text { Case } \\
\text { No }\end{array}$} & \multirow[b]{2}{*}{ Sex } & \multirow[b]{2}{*}{ Age (y) } & \multicolumn{2}{|c|}{ Pituitary gland } & \multicolumn{2}{|c|}{ Occipital cortex } & \multicolumn{2}{|c|}{ Renal cortex } & \multicolumn{2}{|c|}{ Abdominal mus요 } \\
\hline & & & $H g$ & $S e$ & $H g$ & $\mathrm{Se}$ & $H g$ & $\mathrm{Se}$ & $\mathrm{Hg}$ & $S e \overrightarrow{\overline{0}}$ \\
\hline 1 & $\mathbf{M}$ & 24 & $0 \cdot 14$ & $10 \cdot 77$ & 0.050 & 1.90 & 1.63 & $11 \cdot 1$ & - & \\
\hline 2 & M & 48 & 0.08 & 7.92 & 0.012 & 1.43 & $0 \cdot 16$ & $8 \cdot 4$ & 0.005 & \\
\hline 3 & $\mathbf{M}$ & 29 & 0.09 & 6.84 & 0.032 & 1.82 & $1 \cdot 27$ & 11.4 & 0.011 & 2.38 \\
\hline 4 & $M$ & 63 & 0.17 & $5 \cdot 19$ & 0.051 & 1.68 & $0 \cdot 24$ & 7.5 & 0.024 & 1.28 \\
\hline 5 & $M$ & 79 & 0.06 & $5 \cdot 32$ & 0.027 & $1 \cdot 76$ & $0 \cdot 15$ & $8 \cdot 2$ & 0.009 & $1.0 \%$ \\
\hline 6 & M & 73 & 0.08 & 7.09 & 0.020 & 2.00 & 0.11 & $9 \cdot \overline{6}$ & 0.010 & 1.23 \\
\hline 7 & $M$ & 80 & - & - & 0.060 & $2 \cdot 35$ & - & - & 0.024 & 1.73 \\
\hline 8 & $M$ & 71 & 3.88 & 13.93 & 0.114 & 1.96 & 3.79 & $12 \cdot 8$ & 0.047 & $2 \cdot \%$ \\
\hline 9 & $M$ & 74 & 0.08 & $5 \cdot 70$ & 0.046 & 2.00 & 0.29 & $8 \cdot 2$ & 0.022 & 1 . \\
\hline 10 & $\mathbf{M}$ & 40 & 0.15 & $7 \cdot 09$ & 0.053 & $2 \cdot 00$ & 1.57 & $9 \cdot 2$ & 0.017 & 1.39 \\
\hline 11 & $\mathbf{M}$ & 67 & 0.20 & $5 \cdot 70$ & 0.061 & 1.81 & 0.52 & $9 \cdot \overline{7}$ & 0.024 & \\
\hline 12 & $\mathbf{M}$ & 16 & 0.19 & $8 \cdot 23$ & 0.037 & 1.77 & 4.04 & $12 \cdot 4$ & 0.004 & 1.8 \\
\hline 13 & W & 30 & 0.38 & $8 \cdot 36$ & 0.079 & 1.78 & 2.59 & 11.9 & 0.027 & 1.66 \\
\hline 14 & M & 30 & - & - & 0.036 & 1.84 & - & - & - & \\
\hline 15 & $\mathbf{M}$ & 52 & - & - & 0.098 & 2.08 & - & - & - & \\
\hline 16 & $M$ & 76 & 0.08 & $4 \cdot 46$ & 0.049 & 1.92 & - & - & - & \\
\hline 17 & W & 56 & $0 \cdot 14$ & 4.97 & - & - & - & - & - & \\
\hline 18 & $\mathbf{M}$ & 61 & 0.03 & $4 \cdot 79$ & - & - & - & - & - & $-N$ \\
\hline 19 & $M$ & 88 & $0 \cdot 11$ & 4.36 & - & - & - & - & - & ת) \\
\hline 20 & $\mathbf{M}$ & 70 & 5.83 & $10 \cdot 51$ & - & - & - & - & - & - \\
\hline 21 & $M$ & 71 & 0.05 & $6 \cdot 14$ & - & - & - & - & - & \\
\hline 22 & $M$ & 47 & 0.05 & 4.52 & - & - & - & - & - & \\
\hline 23 & W & 75 & 0.19 & 2.75 & - & - & - & - & - & \\
\hline 24 & $\mathbf{M}$ & 63 & 0.04 & $4 \cdot 28$ & 0.081 & $2 \cdot 57$ & - & - & - & \\
\hline \multirow{6}{*}{\multicolumn{2}{|c|}{$\begin{array}{l}\text { No } \\
\text { Min } \\
\text { Max } \\
\text { Median } \\
\text { Average } \\
\text { SD }\end{array}$}} & 24 & 21 & 21 & 17 & 17 & 12 & 12 & & 12 \\
\hline & & 16 & 0.03 & $2 \cdot 75$ & 0.012 & 1.43 & 0.11 & 7.5 & 0.004 & $1 \cdot \overline{8}$ \\
\hline & & 88 & $5 \cdot 83$ & 13.93 & $0 \cdot 114$ & 2.57 & 4.04 & $12 \cdot 8$ & 0.047 & $2 \cdot 38$ \\
\hline & & 63 & $0 \cdot 11$ & $5 \cdot 70$ & 0.050 & 1.90 & 0.89 & $9 \cdot 7$ & 0.020 & 1.52 \\
\hline & & 58 & $0 \cdot 12$ & $6 \cdot 6$ & 0.053 & 1.9 & $1 \cdot 4$ & $10 \cdot 0$ & 0.019 & 1.6 \\
\hline & & 20 & 0.08 & $2 \cdot 6$ & 0.027 & $0 \cdot 26$ & 1.4 & $1 \cdot 7$ & 0.012 & \\
\hline
\end{tabular}

\footnotetext{
*Cases 8 and 20 excluded from the calculation of average and SD for pituitary $\mathrm{Hg}$ concentration.
} 
inactive for months before death. Medical records did not mention signs or symptoms of $\mathrm{Hg}$ intoxication, though one of the dentists (case 2) was investigated before his death for peripheral nerve disorder.

After subsampling and dissection, analysis of total $\mathrm{Hg}$ and $\mathrm{Se}$ was carried out in collaboration with the Swedish Environmental Research Institute (IVL) using a radiochemical neutron activation (RNAA) method. ${ }^{27-29}$ Detailed description and quality control for the $\mathrm{Hg}$ analyses have been published. ${ }^{8}$ The detection limit is $2 \mu \mathrm{g} / \mathrm{kg}$ for Se. The accuracy of the RNAA method (IVL) to determine Se was established by analyses of standard reference material (SRM) 1577a from the National Bureau of Standards (NBS), with a certified value of 0.71 (SD 0.07$) \mathrm{mg}$ $\mathrm{Se} / \mathrm{kg}$ dry weight. The results of three analyses were $0.79,0.75$, and $0.78 \mathrm{mg} \mathrm{Se} / \mathrm{kg}$ dry weight. A few samples (cases 3 and 7 , table 1 ) were analysed by RNAA at Isotopcentralen, Denmark, with a detection limit of $0.2 \mu \mathrm{g} / \mathrm{kg}$ for $\mathrm{Hg}$ and $3 \mu \mathrm{g} / \mathrm{kg}$ for Se. ${ }^{30}$ The accuracy was tested through simultaneous analysis of NBS SRM 1577 certified for 16 (SD 2) $\mu \mathrm{Hg} / \mathrm{kg}$ and $1 \cdot 1$ (SD 0.07) $\mathrm{mg} \mathrm{Se} / \mathrm{kg}$, which gave 16.0 and $15.8 \mu \mathrm{g} \mathrm{Hg} / \mathrm{kg}$ and 1.1 and $1.1 \mathrm{mg} \mathrm{Se} / \mathrm{kg}$.

For the organs with six or more samples the relation between $\mathrm{Se}$ concentrations, $\mathrm{Hg}$ concentrations, and age was investigated by linear regression analysis ${ }^{31}$ with $\mathrm{Se}$ concentration as dependent variable. Examination of residuals indicated that the linear models were adequate. All regression analyses were performed using the SAS statistical package for VAX/VMS. ${ }^{32}$

\section{Results}

MERCURY AND SE IN ORGANS FROM DENTAL STAFF

The highest concentrations of $\mathrm{Hg}$ were seen in thyroid gland and pituitary gland samples. Even though two of the dentists (cases 1 and 2, table 1) had been professionally inactive for a decade or longer, they still had extremely high concentrations in these organs. Tables 1 and 2 show that organs of dental staff had considerably higher $\mathrm{Hg}$ concentrations than those from the general population. They also had higher concentrations of Se. In pituitary gland and occipital cortex tissue differences were significant according to the Mann-Whitney test. ${ }^{33}$

Regression analysis of data from the pituitary glands with Se concentration as dependent variable showed a strong effect of $\mathrm{Hg}$ concentration. The slope coefficient for $\mathrm{Hg}$ was $1 \cdot 1$. Addition of age to the regression equation resulted in a negative regression (slope) coefficient. At zero $\mathrm{Hg}$ concentration and 58 years of age (average age for all the material) the Se concentration predicted by the regression equation was $4.8 \mu \mathrm{mol} \mathrm{Se} / \mathrm{kg}$ (fig 1 and table 3 ). A positive correlation exists $(r=0.34)$ between pituitary Se concentration and age if the effect of $\mathrm{Hg}$ is not considered.

Similar regression analysis of data from the occipital cortices also showed an effect of $\mathrm{Hg}$ concentration. The slope coefficient for $\mathrm{Hg}$ was 1.0 but the confidence interval was wide. The statistical significance of the slope coefficient was dependent on case 1 with the highest concentrations of $\mathrm{Hg}$ and $\mathrm{Se}$ in the occipital cortex. No effect of age was seen. The intercept of $2 \cdot 1 \mu \mathrm{mol} \mathrm{Se} / \mathrm{kg}$ showed a significant fraction of Se not associated with $\mathrm{Hg}$ (table 3).

Too few renal and thyroid samples were taken to make regression analysis meaningful. At the very high concentrations of the elements in one thyroid sample, however (case 2), the stoichiometric ratio of the elements of about $1: 1$ is worth noting.

MERCURY AND SE IN ORGANS FROM SUBJECTS WITHOUT OCCUPATIONAL EXPOSURE TO $\mathrm{Hg}$

The renal cortex had the highest $\mathrm{Hg}$ concentration (table 2). Regression analysis showed a strong influence of $\mathrm{Hg}$ on $\mathrm{Se}$ concentration. The slope coefficient for $\mathrm{Hg}$ was $1 \cdot 1$. No effect of age was seen. The intercept of $8.5 \mu \mathrm{mol} \mathrm{Se} / \mathrm{kg}$ showed that a significant fraction of Se was not associated with $\mathrm{Hg}$ (table 3, fig 2).

Regression analysis of data on Se in the occipital cortices showed a slope coefficient for $\mathrm{Hg}$ of $4 \cdot 6$, but with a wide confidence interval. No effect of age was seen. The intercept of $1.7 \mu \mathrm{mol} \mathrm{Se} / \mathrm{kg}$ indicated that a significant fraction of Se was not associated with $\mathrm{Hg}$ (table 3).

Abdominal muscle had the lowest $\mathrm{Hg}$ concentrations among the tissues studied. Regression analysis showed an effect of $\mathrm{Hg}$ concentration and also a small and borderline significant $(p<0 \cdot 10)$ effect of age on Se concentration in this tissue. The slope coefficient for $\mathrm{Hg}$ was surprisingly high, but the confidence interval was wide (table 3 ).

Regression analysis of data from pituitary gland samples with Se concentration as dependent variable showed a clear effect of both $\mathrm{Hg}$ concentration and

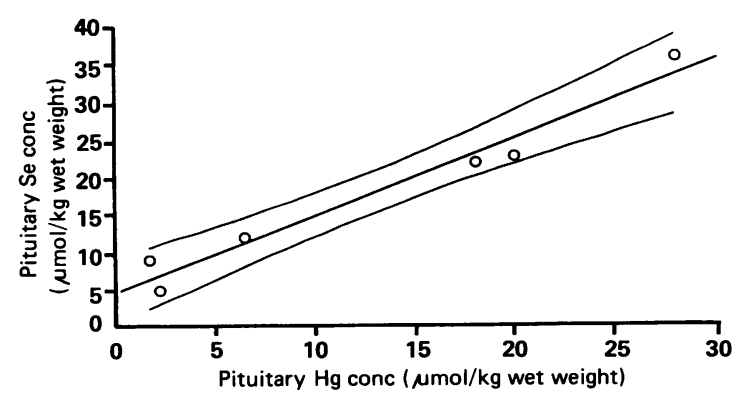

Figure 1 Mercury and Se concentrations ( $\mu \mathrm{mol} / \mathrm{kg}$ wet weight) in pituitary gland samples from dental personnel. Least squares regression line and $95 \%$ CI for the predicted means are shown. 
Table 3 Results of linear regression analysis with Se concentration ( $\mu$ mol/kg wet weight) in different tissues as dependent variable†

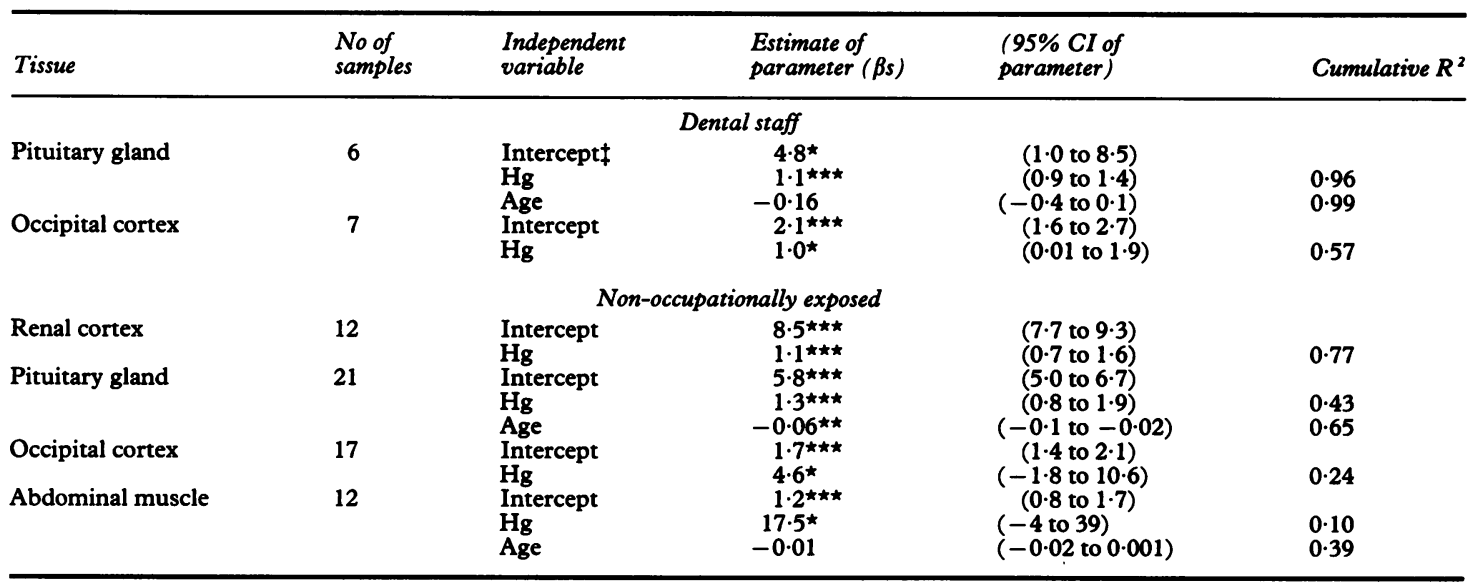

${ }^{\star} \mathrm{p}<0.05 ;{ }^{\star \star} \mathrm{p}<0.01 ;{ }^{\star \star \star} \mathrm{p}<0.001$.

†Model: $[\text { Se }]_{i}=\beta_{0}+\beta_{1} \times[H g]_{i}+\beta_{2} \times \operatorname{age}_{i}+\varepsilon_{i} \varepsilon_{i} N(0, \sigma)$.

In all analyses the concentration of $\mathrm{Hg}$ ( $\mu \mathrm{mol} / \mathrm{kg}$ wet weight) was entered as an independent variable. If significant improvement (partial $F$ test $p<0.15)$ of the model was achieved age was also included in the model. For the analyses where age was included this variable was "centred"- that is, transformed to actual age (y) minus average age of all cases (dental staff plus non-occupationally exposed; that is, 58 years). Significance tests regarding the parameter estimate for the effect of $\mathrm{Hg}$ were performed as one sided $t$ tests and regarding intercept and the effect of age as two sided $t$ tests.

†The parameter $\beta_{0}$ in the model equation-that is, the predicted Se concentration ( $\mu \mathrm{mol} / \mathrm{kg}$ wet weight) at zero $\mathrm{Hg}$ and 58 years of age.

age. The regression coefficient for $\mathrm{Hg}$ was $1 \cdot 3$. The regression coefficient for age was negative-that is, concentrations of $\mathrm{Se}$ decreased with age. At $\mathbf{H g}$ concentration of zero and average age of 58 years the Se concentration predicted by the regression equation was $5.8 \mu \mathrm{mol} \mathrm{Se} / \mathrm{kg}$, showing a significant fraction of Se not associated with $\mathrm{Hg}$ (table 3).

Two cases (8 and 20 ) showed extremely high $\mathrm{Hg}$ concentration in the pituitary (more than 40 standard deviations (SD) above the mean of the rest of the cases; (table 2)) and the source was most likely other than food and amalgams (for instance, occupational). They had retired owing to old age and no data on former occupations were available at the time of sample collection. Later retrieval from the National population and housing census of 1980 showed that one of them had worked as an electrician and thus may have been exposed to mercury through broken electrical equipment. For the other subject no occupational history was obtained.

When the two cases with high pituitary $\mathrm{Hg}$ concentrations were excluded from the analysis the slope coefficient for $\mathrm{Hg}$ remained essentially unchanged, but was no longer statistically significant $\left(R^{2}=0 \cdot 11\right)$. The effect of age remained unchanged $(p<0.01$, cumulative $R^{2}=0.53$ ).

It was notable that $\mathrm{Hg}$ concentrations in the other tissues of case 8 , although comparatively high, were of the same order as in other non-occupationally exposed persons. Exclusion of this case did not change the outcome of the regression analyses for the renal cortices or occipital cortices, but for abdominal muscle the effect of $\mathbf{H g}$ became statistically non- 8 significant.

\section{Discussion}

Concentrations of $\mathrm{Hg}$ in tissues from dental staff were higher than in the corresponding tissues of the general population. Differences were most prominent in pituitary glands (tables 1 and 2). The concomitantly increased Se concentrations in the pituitary glands and in occipital cortices of dental staff show that $\mathrm{Se}$ accumulates together with $\mathrm{Hg}$. Regression analysis showed slope coefficients for $\mathrm{Hg}$ of around unity (table 3 and fig 1). The regression equations thus imply that each increment in $\mathbf{H g}$ concentration

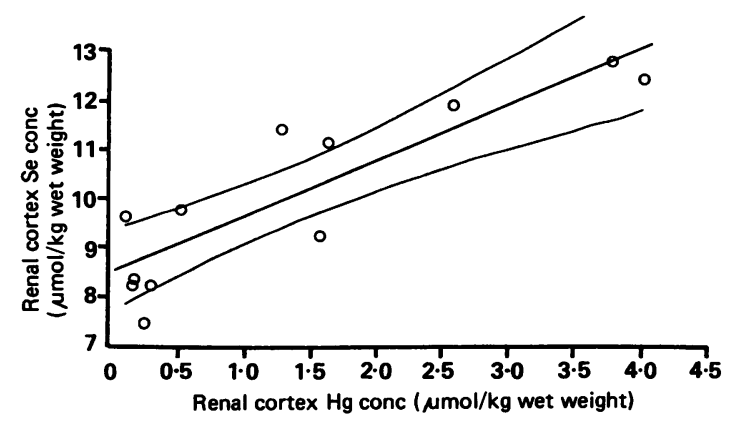

Figure 2 Mercury and Se concentrations ( $\mu$ mollkg wet weight) in renal cortex samples from non-occupationally exposed subjects. Least squares regression line and $95 \% \mathrm{CI}$ for the predicted means are shown. 
results in a roughly equal increment in Se concentration. These results are in close agreement with those of Kosta $e t$ al who found accumulation of Se with $\mathrm{Hg}$ at a 1:1 stoichiometric ratio in several organs from five mercury miners who had retired 5-16 years earlier. ${ }^{25}$

In the additive reaction product of $\mathrm{Se}$ and inorganic $\mathrm{Hg}$, irrespective of whether it is $\mathrm{Hg} / \mathrm{Se}$ or $\mathrm{Hg} / \mathrm{Se}$-protein complex, the stoichiometric ratio of the elements is $1: 1$. Even a slope of unity, however, does not rule out non-associated forms of $\mathrm{Hg}$ - for example methylmercury or $\mathrm{Hg}^{2+}$ bound to protein binding sites-although at the extremely high coefficient of determination in the pituitary glands of dental staff such forms are unlikely to be other than a minor fraction.

Because $\mathrm{Se}$ is essential a certain concentration must be present free of $\mathrm{Hg}$. This concentration is represented by the intercept term in the regression equations. Crude $\mathrm{Hg} / \mathrm{Se}$ ratios from single samples will be confounded by this $\mathrm{Se}$ and are therefore generally not suitable for assessing the association between the elements. With increasing concentration of the elements the effect of free Se can be expected to be reduced and as can be seen from tables 1 and 2 the $\mathrm{Hg} / \mathrm{Se}$ ratio in the samples increases and approaches unity.

Regression analysis of data from non-occupationally exposed persons indicated the accumulation of $\mathrm{Se}$ with $\mathrm{Hg}$ at a rough $1: 1$ stoichiometric ratio in the renal cortex (table 3 and fig 2). An association between the elements, although statistically weaker, was also seen in the occipital cortex, pituitary gland, and abdominal muscle. It is expected that at lower $\mathrm{Hg}$ concentrations only a small amount of $\mathrm{Se}$ is associated with $\mathrm{Hg}$ and natural variations in the much higher concentration of free Se will result in lower statistical correlations. Methylmercury in varying concentrations may also obscure a relation between inorganic $\mathrm{Hg}$ and $\mathrm{Se}$. This source of error could be cancelled by the speciation of $\mathrm{Hg}$. The results are in agreement with a study of Japanese forensic cases from the general population, whic. also showed a high correlation between $\mathrm{Se}$ and $\mathrm{Hg}$ in the kidney but not in the cerebrum. ${ }^{34}$

Selenium in human organs may also bind to metals other than $\mathrm{Hg}$-for example cadmium. ${ }^{34}$ If such binding were of importance here it would most likely have induced variation in Se concentrations that could not be explained by the linear model. The very high coefficients of determination in part of the regression analyses therefore suggest that such binding to other elements was not important. The Se that is free of $\mathrm{Hg}$ thus probably corresponds to biologically available Se. The regression analyses did not indicate a difference in this amount between dental personnel and the general population but an appreciable variation was found between tissues.

Whereas cases without occupational exposure clearly had the highest concentrations of $\mathrm{Hg}$ in the kidneys, occupationally exposed dental staff and retired $\mathrm{Hg}$ miners ${ }^{25}$ showed the highest concentrations of $\mathrm{Hg}$ in the pituitary and thyroid glands. Based on concentration of $\mathrm{Hg}$ in the $\operatorname{air}^{3}$ and urinary excretion of $\mathrm{Hg}^{35-37}$ which is a good indicator of ongoing exposure to $\mathrm{Hg}$ vapour, ${ }^{138}$ the present exposure to mercury in Swedish dentistry has been shown to be moderate. The average contribution of occupational exposure to urinary excretion of $\mathrm{Hg}$ in dental staff was about the same as the average contribution from dental amalgam fillings. ${ }^{35-37}$ The very large difference between pituitary $\mathrm{Hg}$ concentrations in dental staff and non-occupationally exposed subjects is therefore surprising. Three dentists had about 200 times higher mercury concentrations in their pituitary glands than the median for nonoccupationally exposed subjects (tables 1 and 2). One explanation may be higher exposure earlier in Swedish dentistry. Although limited, reports from $1957^{39}$ and $1970^{40}$ do not indicate that exposures to $\mathrm{Hg}$ were previously orders of magnitude higher. (See also Nylander..$^{41}$ ) Another possibility is that the accumulation of $\mathrm{Hg}$ in the pituitary depends not so much on the average exposure but on high exposure peaks when preparing amalgam or when drilling old amalgam fillings. ${ }^{239} 4243$ Such a hypothesis is in line with animal studies by Khayat $e t$ al showing that the increased retention of $\mathrm{Hg}$ after pretreatment with $\mathrm{Se}$ was not seen when the doses of inhaled $\mathrm{Hg}$ vapour and injected Se were small. One hypothesis was that at low concentrations $\mathrm{Hg}$ is bound to sites with low capacity but higher affinity than that of the proposed Se metabolite.4

In the pituitary glands of non-occupationally exposed persons and dental staff the concentrations of biologically available Se decreased with age. Over the age span for the non-occupationally exposed subjects (72 years) the regression equation predicts an age related difference of $72 \times 0.06$ - that is $4.3 \mu \mathrm{mol} \mathrm{Se} /$ $\mathrm{kg}$. The effect of advancing age on Se concentrations in different organs of adults is not well known. In the brain Se concentration has been reported to increase, ${ }^{45}$ but also to decrease ${ }^{46}$ with age. In the renal cortex it has been reported to increase with age. ${ }^{46} \mathrm{We}$ did not find an effect of age on biologically available Se in organs other than the pituitary gland. None of the previous studies considered $\mathbf{H g}$ concentrations, however, and therefore age effects in these studies may be secondary to variations in $\mathrm{Hg}$ concentration that correlated to age.

In conclusion, we have shown accumulation of $\mathrm{Se}$ together with $\mathrm{Hg}$ at a relation consistent with a 1:1 stoichiometric ratio in several organs from dental staff and the general population. The results also show the importance of simultaneous analyses of both $\mathrm{Hg}$ and Se when organ concentrations of these elements are evaluated. 
The work was supported by a grant from the National Environmental Protection Agency.

1 Clarkson TW, Hursh JB, Sager PR, Syversen TLM. Mercury. In: Clarkson TW, Friberg L, Nordberg GF, Sager PR, eds. Biological monitoring of toxic metals. New York: Plenum Press, 1988:199-246.

2 Buchwald $\mathrm{H}$. Exposure of dental workers to mercury. Am Ind Hyg Assoc J 1972;33:492-502.

3 Nilsson B, Nilsson B. Mercury in dental practice. I. The working environment of dental personnel and their exposure to mercury vapor. Swed Dent J 1986;10:1-4.

4 Cook TA, Yates PO. Fatal mercury intoxication in a dental surgery assistant. Br Dent $J 1969 ; 127: 533-5$.

5 Iyer K, Goodgold J, Eberstein A, Berg P. Mercury poisoning in a dentist. Arch Neurol 1976;33:788-90.

6 Smith DL. Mental effects of mercury poisoning. South Med J 1978;71:904-5.

7 Enwonwu CO. Potential health hazard of use of mercury in dentistry: Critical review of the literature. Environ Res 1987;42:257-74.

8 Nylander M, Friberg L, Lind B. Mercury concentrations in the human brain in relation to exposure from dental amalgam fillings. Swed Dent J 1987;11:179-87.

9 Weiner JA, Nylander M, Berglund F. Does mercury from amalgam restorations constitute a health hazard? Sci Total Environ 1990;99:1-22.

10 Eggleston DW, Nylander M. Correlation of dental amalgam with mercury in brain tissue. J Prosthet Dent 1987;58:704-7.

11 Nylander M, Friberg L, Eggleston D, Björkman L. Mercury accumulation in tissues from dental staff and controls in relation to exposure. Swed Dent J 1989;13:235-43.

12 Schiele R. Quecksilberabgabe aus amalgam und quecksilberablagerung in organismus und toxikologische bewertung. In: Knolle G, ed. Amalgam-pro und contra. Statements-discussion. Köln: Deutsche Ärzte-Verlag, 1988: 123-31.

13 Clarkson TW, Friberg L, Hursh JB, Nylander M. The prediction of intake of mercury vapor from amalgams. In: Clarkson TW, Friberg L, Nordberg GF, Sager PR, eds. Biological monitoring of toxic metals. New York: Plenum Press, 1988: $247-64$.

14 Burk RF, Foster KA, Greenfield PM, Kiker KW. Binding of simultaneously administered inorganic selenium and mercury to a rat plasma protein. Proc Soc Exp Biol Med 1974;145: $782-5$.

15 Chen RW, Whanger PD, Fang SC. Diversion of mercury binding in rat tissues by selenium: a possible mechanism of protection. Pharmacol Res Commun 1974;6:571-9.

16 Fang SC. Interaction of selenium and mercury in the rat. Chem Biol Interact 1977;17:25-40.

17 Naganuma A, Imura N. Properties of mercury and selenium in a high-molecular weight substance in rabbit tissues formed by simultaneous administration. Pharmacol Biochem Behav 1981;15:449-54.

18 Eybl V, Sykora J, Mertl F. Einfluss von natriumselenite, natriumtellurit und natriumsulfit auf retention und verteilung von quecksilber bei mäusen. Arch Toxiol 1969;25:296-305.

19 Hansen JC, Kristensen P. Organ clearance of ${ }^{75} \mathrm{SeO}_{3}{ }^{2-}$ and ${ }^{203} \mathrm{HgCl}_{2}$ administered separately and simultaneously to mice. Toxicology 1979;15:1-7.

20 Groth DH, Stettler L, Mackay G. Interactions of mercury, cadmium, selenium tellurium, arsenic and beryllium. In: Nordberg GF, ed. Effects and dose-response relationships of toxic metals. Amsterdam: Elsevier, 1976:527-43.

21 Khayat A, Dencker L. Interactions between selenium and mercury in mice: marked retention in the lung after inhalation of metallic mercury. Chem Biol Interact 1983;46:283-98.

22 Kristensen $\mathrm{P}$, Hansen JC. Wholebody elimination of ${ }^{75} \mathrm{SeO}_{3}{ }^{2-}$ and ${ }^{203} \mathrm{HgCl}_{2}$ administered separately and simultaneously to mice. Toxicology 1979;12:101-9.

23 Koeman JH, van de Ven WSM, de Goeij JJM, Tjioe PS, van Haaften JL. Mercury and selenium in marine mammals and birds. Sci Total Environ 1975;3:279-87.
24 Kari T, Kauranen P. Mercury and selenium contents of seals from fresh and brackish waters in Finland. Bull Environ Contam Toxicol 1978;19:273-80.

25 Kosta L, Byrne AR, Zelenko V. Correlation between selenium and mercury in man following exposure to inorganic mercury. Nature 1975;254:238-9.

26 Nylander M, Weiner J. Relation between mercury and selenium in pituitary glands of dental staff. BrJ Ind Med 1989;46:751-2.

27 Sjöstrand B. Determination of mercury and arsenic in biological and organic material by activation analysis. Anal Chem 1964;36:814-9.

28 Ljunggren K, Johnels AG, Olsson M, Otterlind G, Sjöstrand B, Westermark $T$. Activation analysis of mercury and other environmental pollutants in water and aquatic ecosystems. In Nuclear techniques in environmental pollution. Vienna: IAEA, 1971;373-405.

29 Dusan B, Kristiansson S, Lundberg $\AA$, Skärdin I-L, Werner J, Österdahl G. Routine analyses of mercury. A comparative study between two methods; neutron activation and flameless atomic absorption. Stockholm: The Swedish Environmental Research Institute, 1984. (Report B758.)

30 Drabaek I, Carlsen V, Just L. Routine determination of mercury, arsenic and selenium by radiochemical neutron activation analysis. Journal of Radioanalytical and Nuclear Chemistry, Letters 1986;4:249-60.

31 Draper NR, Smith H. Applied regression analysis, 2nd ed. New York: John Wiley \& Sons, 1981.

32 SAS Institute. $S A S$ user's guide: statistics. Version 5. Cary, North Carolina: SAS Institute, 1985.

33 Snedecor GW, Cochran WG. Statistical methods, 7 th ed. Ames, Iowa: The Iowa State University Press, 1987:144-5.

34 Yoshinaga J, Matsuo N, Imai H, et al. Interrelationship between the concentrations of some elements in the organs of Japanese with special reference to selenium-heavy metal relationships. Sci Total Environ 1990;91:127-40.

35 Nilsson B, Nilsson B. Mercury in dental practice. II. Urinary mercury excretion in dental personnel. Swed Dent J 1986; 10:221-32.

36 Skare S, Bergström T, Engqvist A, Weiner JA. Mercury exposure of different origins among dentists and dental nurses. $S$ cand J Work Environ Health 1990;16:340-7.

37 Åkesson I, Schütz A, Attewell R, Skerfving S, Glantz PO. Status of mercury and selenium status in dental personnel-impact of amalgam work and own fillings. Arch Environ Health 1991; 46:102-9.

38 Roels H, Abdeladim S, Ceulemans E, Lauwerys R. Relationships between the concentration of mercury in air and in blood or urine in workers exposed to mercury vapour. Ann Occup Hyg 1987;31:135-45.

39 Frykholm KO. Mercury from dental amalgam its toxic and allergic effects and some comments on occupational hygiene. Acta Odontol Scand 1957;15:1-108.

40 Frykholm KO. Exposure of dental personnel to mercury during work. Swed Dent J 1970;63:763-72.

41 Nylander M. Accumulation and biotransformation of mercury and its relationship to selenium after exposure to inorganic mercury and methyl mercury-a study on individuals with amalgam fillings, dental personnel and monkeys. Stockholm: Karolinska Institute, 1990. ((Paper VIII) Doctoral thesis.)

42 Reinhardt JW, Chan KC, Schulein TM. Mercury vaporization during amalgam removal. J Prosthet Dent 1983;50:62-4.

43 Richards JM, Warren PJ. Mercury vapour released during the removal of old amalgam restorations. $B r$ Dent $J$ 1985;155: 231-2.

44 Khayat A. Disposition of metallic mercury vapor and mercuric chloride in adult and fetal tissues: influence of pretreatment with ethyl alcohol, aminotriazole, selenium, and tellurium. Uppsala: Uppsala University, 1985. (Doctoral thesis.)

45 Duflou H, Maenhaut W, De Reuck J. Regional distribution of potassium, calcium, and six trace elements in normal human brain. Neurochem Res 1989;14:1099-112.

46 Persigehl M, Schicha H, Kasperek K, Feinendegen LE. Behaviour of trace element concentration in human organs in dependence of age and environment. Journal of Radioanalytical Chemistry 1977;37:611-5.

Accepted 18 March 1991 